\title{
ACTIVE METHODOLOGIES: ANALYSIS OF CONTEXT AND THE IMPLICATION IN THE USE OF TWO DIFFERENT METHODS
}

\author{
Carla Campana, Pablo Leão and Caio César Coelho \\ FGV/EAESP \\ Rua Itapeva, 474 - 8 floor Bela Vista 01332000- São Paulo-SP, Brazil
}

\begin{abstract}
Active methodologies are being used to teach different contents to business students. Most studies compare traditional and active methods. The shift between the lecture centered to the student center methods, however, does not occur lightly. Our purpose is to describe points of attention when applying active methodologies to business under graduation students. We carry two intrinsic case studies that when read may improve teachers and facilitators to change their strategy in the classroom. We describe two different active methodologies of teaching/learning the Flipped Classroom and an Integrated Leadership Program. We found out that the context and history of students with the methodology is a key point for its acceptance. Also, the preparation of the class and the transparency with the methodology are essential for its functionality.
\end{abstract}

\section{KEYWORDS}

Active Methodologies, Business Teaching, Case Study, Flipped Classroom, Learning Process

\section{INTRODUCTION}

The higher education is under pressure to transform itself. That pressure results from changes of information technology, interactivity tool, analytical capacity and customization. Big data, technological, economic and social developments disturbed the educational process. Increasingly the encyclopedia teaching is being considered inefficient in preparing students to the contemporary demands. This urgency puts universities and business schools in a run for innovations in teaching processes. In this context, different teaching practices are being developed and applied to attract the attention of students and to assure that they learn the capacities required by the labor market.

Recently business education has passed through a transformation in order to make the classroom a more interactive environment, in this context, new didactic practices were designed, becoming known as active methodologies. Such practices do not take students as mere passive subjective of a lecture or class, they are teaching and learning methodologies that encourage students to take part and interact during the learning process (Urias and Azeredo, 2017). Most studies have compared traditional and active methods (Park and Choi, 2014), others have observed the impact of technology on teaching methods (Spinelli, 2001). However, not every active methodology works the same way for different contexts since it is an approach that needs to consider the singularity of each classroom (Urias and Azeredo, 2017). Our purpose is to describe two active teaching and learning methodologies and extract points of attention when applying it. .

Most studies focus on the differences between active and traditional methods; however, a range of active methods has been developed and applied around the globe. In this sense, we contribute to the discussion of active methods, describing and highlighting points of attention in in implementing active teaching and learning methods. In this sense the question that guides our study is: which factors influence the implementation of active teaching and learning methodology?

We focus on two intrinsic case studies of active methodologies approaches that had different outcomes. The first case is a Flipped Classroom methodology applied to a first-year statistics mandatory class for business undergraduate course. The second program, the Integrated Education for Entrepreneurial Leadership (Intent), is a class based on Carl Rogers (2003) humanistic psychology approach and in his concept of client-centered 
therapy, and it also draws from Lewin's (1948) group dynamics methodology. These intrinsic cases were selected due to their relevance and contribution to the subject, in this sense, the cases can reveal possible insights and points of attention to the reader, contributing to further understand and applying active methodologies (R. E. Stake, 1998). To construct the thick qualitative description of both cases we used both courses' syllabus and the student's evaluation of the course, interviews with the professor and the students of the Flipped Classroom and Intent classes. Additionally, two of the authors actively participated and observed the classes that applied the Intent methodology.

With their description it is possible to pinpoint that not every practice of the new teaching and learning methods will work on every occasion. In this sense, it is also possible to elaborate some points of attention when applying active methodologies. Both methodologies are active learning and teaching methodologies, however, they demonstrate to have very different outcomes, which are mostly influenced by the context/moment in which they are applied and the students' expectations when enrolling in the course. This study aims to contribute to such discussion by informing scholars and practitioners about the specifics of active methodology application in the context of an undergraduate business course.

The articles follow with a literature review on traditional and active methodologies of teaching and learning. After that we explain the theory behind the methods of the Flipped Classroom and the Intent. We give sequence by describing our methodology and our data sources, then we go to the analysis with the description of both cases. Finally, we present the conclusions with our contributions, limitations and suggestions for future studies.

\section{LITERATURE REVIEW}

Both active and traditional practices have great variety and accommodate different conceptions and purposes. To simplify, we understand the traditional model as common and hegemonic practices in the teaching and learning process. Active methods, on the other hand, are centered on learning with the active participation of students. Here we better define traditional and active methods. Then we cover the basic assumptions of both methods that we studied, the Flipped Classroom and the Intent project.

Traditional methods can be defined as the lecturing method. It has a few assumptions that has been used recurrently. The first assumption is the idea that the students will learn equally from the explanation of the professor. Therefore, the teacher has the knowledge that must be passed to the students in the same rhythm and approach to the entire class. Lecturing, by definition, is the use of explanation types to make students understand a specific content (Behr, 1988).

Along with the lecturing method comes the assessment methods. Commonly the students are assessed by more than one delivery. However, the final exam is recurrently a way to assess what the student learned. Other methods such as group projects, papers can also be used (Miller, Imrie and Cox, 2013). Traditionally tests and exams are the most frequently used way of assessment, however they evaluate the student at the end of a course. That inhibits the capacity of the student to improve their learning outcomes during the course (Michlitsch and Sidle, 2002).

Active methods, on the other hand, puts a more central role to the student. They actively engage in the learning process, contributing with each other. It is possible to observe three underlying assumptions of this method. Firstly, the students must be interested in the content, without interest they will not engage with the activities (Sivan et al., 2000). Secondly, the teacher is not only a lecturer, he or she portrays the role of facilitator creating a connection with the learner (Kelly, 2016). Finally, the learning process uses planned activities that involve technology, dynamics and group formation (Goldfinch, 1996; Spinelli, 2001).

The assessment methods on active methodology can use final exams and tests. However, the ongoing deliveries of projects made by the students can also be assessed during the course. That allows the students to increase their learning outcomes during the classes. Of course, different assessment methods can be used in both traditional and active methods. Still, active methods allow the teacher to have different forms of learning outcomes and assessments and allow the students to improve their learning strategy during the courses (Michlitsch and Sidle, 2002).

We defined traditional and active methods. Active methods comprehend a variety of techniques that involves the student in the teaching and learning process. Now it is possible to deepen our understanding on the active methods that we will analyze: The Flipped Classroom and the Intent initiative. 
One approach that shows promise is flipping the classroom. This refers to students using time outside of class (that is traditionally reserved for homework) to learn material, usually by watching video-lectures, while in-class time (traditionally reserved for lecturing) is used for some form of interactive group learning activity for which the instructor acts as learning coach and consultant. (Swart and Wuensch, 2016, p.68)

The flipped classroom was disseminated by Bergmann and Sams (2012) as a way to increase the contact of teachers and students, to deepen the students learn on important abilities such as group work and to use the time inside the class and outside of it differently and more efficiently. With this method the student detains the control of its own learning rhythm (Tucker, 2012).

Specifically, for the Flipped Classroom, there are studies showing that the method may interest the students more, however the learning outcome is the same as the traditional methods (Findlay-Thompson and Mombourquette, 2014). There is supporting empirical evidence that the Flipped Classroom attracts the attention of Millennial students (Phillips and Trainor, 2014) but it needs to be structured to use the in-class time efficiently (Butt, 2014).

Our Flipped Classroom case was used to teach a mandatory course of basic statistics. Active methodologies have already been used to teach statistics. The use of technology and primarily statistics programs and the learning by doing process are common methods to teach statistics for business. In one of those experiences small group classes where preferred by students and staff (Goldfinch, 1996). In the experience of using computers, if the courses are well planned both traditional and active methods are effective and there is no difference for the learning outcomes (Spinelli, 2001).

Other active methods have been used to teach entrepreneurship skills. A combination of active and lecture methods was used in the Babson college to expose the students to the United States entrepreneurial environment. The results of that experience showed the importance of mixing lectures with active methods (Lourenço and Jones, 2006). Arasti, Falavarjani and Imanipour (2012) recommends the case studies, individual assignments, group projects, problem-solving and development of a business plan to teach entrepreneurship for graduate students.

The Intent initiative, however, is an integrated training program that aims to develop skills and competencies related to entrepreneurship and leadership. It is based on a safe pedagogical space, focused on experimentation and reflexivity. Its foundations are based on the the idea that the student is autonomous. He or she can deal with the constructive aspects of its life, seeking solutions and find the directions to have a satisfactory life (Rogers, 2003). The active and continuous learning require that the professor is less directive and more respectful given the protagonism to the student.

The intent practices is inspired by the Kaospilot business school on denmark. The helped with the program design. Some of their contributions involve the team formation approach, the integrated and experience learning and creative leadership.

\section{METHODS}

This study is based on a qualitative research in order to study two distinct cases of teaching/learning methodologies and to thoroughly describe their success and failure factors. In this sense, we conducted a multiple and intrinsic case study. The case study is appropriate when trying to understand in depth from an example how a phenomenon empirically occurs (Eisenhardt, 1989; Robert E Stake, 1998).

At a prestigious business school located in the city of São Paulo, two different subjects were taught to undergraduate students by the same teacher. In one discipline the Flipped Classroom methodology was used to teach basic statistics. In the other a discipline called Intent was developed with the aim of developing skills and competencies related to entrepreneurship and leadership.

We choose the two courses because they were though by the same professor and had different acceptance by the students. Through a final report of the two courses we realized that Intent was better accepted than the Flipped Classroom. The two theoretically and empirically relevant cases show us different aspects of active methodologies. From the description of the students and of the teacher we can describe which were the factors that possibly led to greater acceptance of either methodology (Eisenhardt, 1989).

The cases were chosen based on their empirical and theoretical relevance. That is, the two extremes of active methodologies. One having a positive student rating and the other a negative, allow their description to 
bring interesting insights to management teaching theory (Yin, 2003). Also, in this sense, the Flipped Classroom and Intent were conducted within the same institutional context and are the units of analysis of this study.

We used different types of data for each case in order to give a comprehensive view of both courses. For both methodologies we analyzed the syllabus to understand and describe the objectives of the courses. We also used the evaluation forms answered by the students at the end of the course's classes and interviews with students and the professor in both initiatives.. A summary of the data sources and their contribution to the cases can be seen in table 1 .

To analyze that data, we were inspired by the codification approach of the grounded theory. Drawing from this inductive analysis we read and coded the data by searching for similarities and contradictions in the informant's perception of the classes. We can describe the cases and their analyzes on the next section (Charmaz, 2000).

\section{CASES DESCRIPTIONS}

The Flipped Classroom was a compulsory discipline of Statistics 1 . The classes had approximately 45 students each and were held twice a week, in periods of one hour and forty minutes. The students were not informed of any change in the way the discipline would be conducted and had not chosen to be part of the classes they were in. During the classes there was no exposure on the indicated topics. In-class time was spent conducting group exercises that reflected problem situations in the daily life of a business manager. Students could use whatever resources they wanted to solve the exercises and the teacher was present to assist the groups. When observing a recurring doubt, the teacher made brief explanations for the class. The evaluation of the course consisted of a grade of participation, measured by quick assessments and group activities during the classes; a partial test and a final test. The partial and final tests were unified among all Statistics 1 courses of the semester.

Intent is an elective program for students of Business and Public Administration. It receives approximately 20 students per semester. Students wishing to be part of Intent apply and participate in a selection process. Intent's goal is to develop, through practical activities, skills and competencies such as leadership, communication, feedback, group work, active listening, sense of direction and autonomy. The meetings take place from Monday to Thursday, from 9am to 4pm. During the meetings, team leaders, as teachers are called, are responsible for designing and sustaining a learning space from experience, and team members are encouraged to develop their own individual or group projects independently, including on your own learning. There are no lectures and students are free to interact with the bibliography indicated before the course.

Team members evaluation has three main components, each referring to one of the three cycles that make up the program. In Cycle 1, which contemplates the formation of the team, the assessment is given by reflection on one's own learning, which occurs through the weekly delivery of a reflective diary. In Cycle 2, which involves the realization of a personal project, peers and team leaders are evaluated by completing a rubric. In Cycle 3, which provides consulting services to a real client, the evaluation comes from a panel of external professionals invited to evaluate the results and the consulting process.

\section{ANALYSIS}

Analyzing both methodologies and the context in which they were applied we found points of attention which must be considered. In the case of the Flipped Classroom, it became clear in our analysis that the autonomy and the extra time to study required by such a method are the main stressed point for students. They have a high expectation to continue with the traditional method of learning, in which professors assume the role of leader and knowledge keeper offering full lectures about a concept and then follow a well-known and structured process with exercises and tests. These findings are especially true during the first semesters when the influence of a traditional methodology is stronger because of students' history with their middle school experience. Additionally, students demonstrate to not be prone to change. They would rather deal with a method that is familiar to them and, from their perspective, is less time-consuming. "And in the statistics (class) we don't have lectures and I can do it. I simple like that [lecture]. It goes exactly against what I have always done. I am 
lost" (Mary) When the professor is asked about students' resilience: (...) "I think they don't have... Anyway, they still think they are in a [kind of] high school." (Professor)

On the other side, students who have participated in the Intent program demonstrated a high level of interest and satisfaction with the method. "[Intent] was a turnaround, it was way beyond my expectations, it was something that I was needing, needing a lot" (José). We noticed some contextual and methodological reasons for that. For instance, students who participate in this program are selected based on their interest in being part of it, what might increase the level of satisfaction. Another important point that has emerged from our analysis is the context in which Intent happens. Most students are in the sixth semester and by then they might have accumulated great experience with other courses, international exchange programs and are getting ready to search for an internship. "It has been an amazing feeling about I have evolved in the last year, first because I did the exchange program (...) and the Intent was a good transition (...) it has been a great transition. (Cabral) Closely related to the latter, the Intent program covers competencies that students are seeking at this moment in life, such as, self-awareness, group work, and a real word experience project. One of the students point one of hers takeaway: "[INTENT] helped me a lot in [creating] self-awareness. I look myself; I observe myself, and how I act in the group, how I act in the team." (john).

\section{CONCLUSION}

We advance in the research of active methods of teaching and learning but describing two intrinsic case studies of that method. We did not aim to compare traditional and active methods nor to compare the Flipped Classroom and the Intent. We contribute by providing a series of points of attention with which a professor who may use active methodologies must be aware of. Also, we bring the the teaching and learning theories the importance of reflect upon their own methods before applying them to business students.

Reading through both cases it is possible to see that the professor needs to be prepared to give a class with active methods. That is, it is important to have the material prepared, to be aware that students will take a more active role in the classroom, but also may engage in resistance practice. Both cases brig our attention to the context of the students, they had different perception about the active methodologies based on obligation of doing the discipline, its moment in the course and the amount of activities outside the classes.

We acknowledge our limitations to contribute to a theory that generalizes our points of attention. However, the chosen methodology of intrinsic case studies allows us to contribute to the reflection upon active methodologies and its practical applications. Future studies can embrace the points of attention in a way to explore them with a broader view. Also, we encourage researchers to use intrinsic case studies to investigate active methodologies. To tell stories about those methodologies help other teachers to apply its methods on their classes and be aware of their possible problems and contributions.

\section{REFERENCES}

Arasti, Z., Falavarjani, M. K. and Imanipour, N. (2012) 'A Study of Teaching Methods in Entrepreneurship Education for Graduate Students', Higher Education Studies, 2(1), pp. 2-10. doi: 10.5539/hes.v2n1p2.

Behr, A. L. (1988) 'Exploring the Lecture Method: An empirical study', Studies in Higher Education, 13(2), pp. 189-200. doi: 10.1080/03075078812331377866.

Bergmann, J. and Sams, A. (2012) ‘Flip Your Classroom: Reach Every Student in Every Class Every Day’, International Society for Technology in Education.

Butt, A. (2014) 'Student Views on the Use of a Flipped Classroom Approach: Evidence from Australia', Business Education \& Accreditation, 6(1), p. 33.

Charmaz, K. (2000) 'Grounded theory: Objectivist and contructivist methods', in Denzin, N. K. and Lincoln, Y. (eds) The Handbook of Qualitative Research. Thousand Oaks, CA: Sage publications, pp. 509-35.

Eisenhardt, K. M. (1989) 'Building Theories from Case Study Research', The Academy of Management Review, 14(4), pp. 532-550.

Findlay-Thompson, S. and Mombourquette, P. (2014) 'Evaluation of a Flipped Classroom in an Undergraduate Business Course', Business Education \& Accreditation, 6(1), pp. 63-73. doi: 10.1080/08832323.1963.10116709. 
Goldfinch, J. (1996) 'The Effectiveness of School-type Classes Compared to the Traditional Lecture/Tutorial Method for Teaching Quantitative Methods to Business Students', Studies in Higher Education, 21(2), pp. 207-220. doi: $10.1080 / 03075079612331381368$.

Kelly, C. (2016) 'Teacher as facilitator of learning', in Mårtensson, P. and Bild, M. (eds) Teaching and Learning at Business Schools: Transforming Business Education. CRC Press, p. 330.

Lewin, K. (1948) Resolving Social Conflicts, Selected Papers on Group Dynamics (1935-1946). New York: Harper.

Lourenço, F. and Jones, O. (2006) 'Developing entrepreneurship education: comparing traditional and alternative teaching approaches', International Journal of Entrepreneurship Education, 4(1), pp. 111-140.

Michlitsch, J. F. and Sidle, M. W. (2002) 'Assessing Student Learning Outcomes: A Comparative Study of Techniques Used in Business School Disciplines', Journal of Education for Business, 77(3), pp. 125-130. doi: 10.1080/08832320209599060.

Miller, A. H., Imrie, B. W. and Cox, K. (2013) Student assessment in higher education: a handbook for assessing performance. london and New York: Routledge/Taylor \& Francis.

Park, E. L. and Choi, B. K. (2014) 'Transformation of classroom spaces: traditional versus active learning classroom in colleges', Higher Education, 68(5), pp. 749-771. doi: 10.1007/s10734-014-9742-0.

Phillips, C. and Trainor, J. (2014) 'Millennial students and the flipped classroom', ASBBS Annual Conference: Las Vegas, $5(1)$, p. 102.

Rogers, C. (2003) Client Centered Therapy. Its current practice, implications and theory. London: Constable.

Sivan, A. et al. (2000) 'An implementation of active learning and its effect on the quality of student learning', Innovations in Education and Teaching International, 37(4), pp. 381-389. doi: 10.1080/135580000750052991.

Spinelli, M. A. (2001) 'The Use of Technology in Teaching Business Statistics', Journal of Education for Business, 77(1), pp. 41-44. doi: 10.1080/08832320109599669.

Stake, R. E. (1998) 'Case studies’, in Strategies of Qualitative Inquiry. California: Sage Publications, pp. 445-454.

Stake, Robert E (1998) 'Qualitative case studies.' Sage Publications, Inc.

Swart, W. and Wuensch, K. L. (2016) 'Flipping Quantitative Classes: A Triple Win', Decision Sciences Journal of Innovative Education, 14(1), pp. 67-89. doi: 10.1111/dsji.12088.

Tucker, B. (2012) 'The flipped classroom: Online instruction at home frees class time for learning.', Education Next, 12.

Urias, G. M. P. C. and Azeredo, L. A. S. de (2017) 'Metodologias ativas nas aulas de Administração Financeira: alternativa ao método tradicional de ensino para o despertar da motivação intrínseca e o desenvolvimento da autonomia', Administração: Ensino e Pesquisa, 18(1), p. 39. doi: 10.13058/raep.2017.v18n1.473.

Yin, R. K. (2003) Case Study Research Design and Methods. 3rd edn. Thousand Oaks, CA: Sage Publications. 